\title{
ASSESMENT OF ANTIFUNGAL ACTIVITY OF A CYANOBACTERIUM CALOTHRIX JAVANICA DE WILDE
}

\author{
J.N. Nehul \\ Dada Patil Rajale College, Adinathnagar Tal-Pathardi Dist-Ahmednagar- 414505(MS) India \\ *Corresponding Author: jnnehul@gmail.com
}

\begin{abstract}
:
A cyanobacterium Calothrix javanica was isolated from the collected soil samples from different locations. Identification was carried out using morphological variation and taxonomical approaches according to Desi kachary (1959) and Prescott (1962). The axenic culture of Calothrix javanica was obtained by using the method recommended by Bolch and Blackburn (1996). The isolated species of Calothrix javanica was grown autotropically in BG-11 medium as described by Rippka et al., (1979) and incubated at $30 \pm 2{ }^{\circ} \mathrm{C}$. After 25 days, biomass was harvested by filtration through double layered muslin cloth and dried using air blower. The biomass of this Calothrix javanica species was used for the assessment of antifungal activity against Aspergillus niger, Trichophyton capitanum, Aspergillus flavus, Fusarium Monelliforme, Helminthosphorium sp., Alternaria sp. and Candida albicans. In the light of the experimental result concerning the antifungal activity against the tested fungal organisms, the results recorded clearly showed that the methanol extracts of Calothrix javanica towards the tested fungi gave positive results.
\end{abstract}

Key words: - Calothrix javanica, Antifungal Activity, BG-11, Candida albicans, Alternaria sp.

\section{INTRODUCTION:}

Fungal infections remain a significant cause of morbidity and mortality despite the advances in medicines and the emergence of new antifungal agents (McNeil et al., 2001). Candida albicans, the agent of candidiasis, is an increasingly important disease that has a worldwide distribution due to the fact that it is a frequent opportunistic pathogen in AIDS patients (De Pavia et al., 2003). It is commonly found in the gastrointestinal and urinogenital tracts of human (Black, 1996). The available antifungal drugs produce many adverse effects, show reappearance or lead to the development of resistance. Therefore, the new antifungal agents without these disadvantages are strongly needed (Selitrennikoff, 2001).

Screening of cyanobacteria for antibiotics and other pharmacologically active compounds has received ever-increasing interest as a potential source for new drugs (Borowitzka 1995, Fish and Codd, 1994, stensvik et al., 1998, Schlegel et al., 1999). Several species of cyanobacteria produce substances with antibiotic activity. Antifungal activity was observed in a large percentage of the cyanobacterial extracts tested (Ishibashi et al., 1986). The cryptophycins comprise the largest class of cyanobacterial depsipeptides (Trimurtulu et al., 1994) in which cryptophycin-1, was isolated from Nostoc sp. ATCC 53787 as an antifungal agent (Hirsch et al., 1990). The scytophycins are also found to be potent antifungal agents (Patterson and Carmeli, 1992). Scytophycins are highly cytotoxic and fungicidal macrolides. In spite of the studies carried out so far, many cyanobacterial compounds are still largely unexplored, thus giving a great opportunity for the discovery of a new bioactive compound. 
The expected rate of discovery is far lower than that of other better-studied group of organisms (Olaizola, 2003).

Therefore the aim of the current research was to investigate the antifungal activity of Calothrix javanica isolated from terrestrial habitat of Ahmednagar district of Maharashtra state, India.

\section{MATERIALS AND METHODS:}

\section{Collection, Isolation and Identification of Westiellopsis prolifica}

Calothrix javanica was isolated from the collected soil samples from different locations. The axenic culture of Calothrix javanica was obtained by using the method recommended by Bolch and Blackburn (1996). The isolated Calothrix javanica was grown auto tropically in BG-11 medium as described by Rippka et al., (1979) and incubated at $30 \pm 2{ }^{\circ} \mathrm{C}$. Identification was carried out using morphological variation and taxonomical approaches according to Desikachary (1959) and Prescott (1962).

\section{Extraction procedure}

Five $\mathrm{g}$ of finely powdered biomass was successively extracted in $50 \mathrm{ml}$ of chloroform, methanol, hexane and water by using soxhlet apparatus at $40^{\circ} \mathrm{C}$ for $24 \mathrm{~h}$. The filtered extract was concentrated in vacuo at $40^{\circ} \mathrm{C}$. Final volume of the extract was made $1 \mathrm{ml}$ with respective solvents.

\section{Test organisms}

Pure cultures of Aspergillus niger, Trichophyton capitanum, Aspergillus flavus, Fusarium Monelliforme, Helminthosphorium sp., Alternaria $s p$. and Candida albicans were procured from NCIM, NCL, Pune and used for antifungal assay. Test cultures were grown on $25 \mathrm{ml}$ potato dextrose agar of composition (in $\mathrm{g}$ $\left.\mathrm{L}^{-1}\right)$ potato $200 \mathrm{~g}$, dextrose 20 , and agar 20 at pH 5.6 for sporulation in $500 \mathrm{ml}$ Erlenmeyer flasks. Only Candida albicans was grown on
MGYP medium. Spore suspension was prepared by pouring $5 \mathrm{ml}$ sterile $0.01 \%$ triton $\mathrm{X}-100$ solution, vortexing for $1 \mathrm{~min}$ and sieving through cheesecloth. Final inoculum density of $10^{6}$ spores $\mathrm{ml}^{-1}$ was calibrated using a hemocytometer.

\section{Screening of isolates for antifungal activity Agar diffusion assay}

Agar wells were prepared with borer and poured with $400 \mu 1$ extracts of Calothrix javanica, dried, and placed on potato dextrose agar plates, prior inoculated with $0.1 \mathrm{ml}$ fungal spore suspension (1 X106 spores $\mathrm{ml}^{-1}$ ). Antifungal activity was assessed by measuring the diameter of growth inhibition zone after incubation at $30^{\circ} \mathrm{C}$ for $48 \mathrm{~h}$. Itraconazol ( Hi Media, India) was used as the positive control at $10 \mu \mathrm{g} \mathrm{ml}-1$ concentrations.

\section{RESULTS AND DISCUSSION:}

In the light of the experimental result concerning the antifungal activity against the tested fungal organisms, the results recorded in Table -1 clearly showed that the antifungal activity of the methanol extract of Calothrix javanica towards the tested fungi gave positive results but with varying degree. Methanol extract of Calothrix javanica gave the largest inhibition zones against Aspergillus flavus. Methanol extract exhibited activity against all the tested fungi and the zone of inhibition ranged from $06 \mathrm{~mm}$ to $17 \mathrm{~mm}$.

Activity of chloroform extract shown by Calothrix javanica was only against Aspergillus niger and Aspergillus flavus.No activity of chloroform extract was shown by Calothrix javanica against Trichophyton capitanum, Fusarium monelliform Candida aibicans, and Helminthosporium sp. Hexane and aqueous extracts did not show any activity against any tested fungal organism. Results are the mean of diameter values \pm standard deviation. Effective zone of inhibition 
$=($ Total zone of inhibition minus diameter of disk). A few studies have been carried out to screen Calothrix javanica species for production of antimicrobial substances from paddy-fields. Possibly the synthesis of highly active toxin is a defense option of cyanobacteria in these environments against other organisms like bacteria, fungi, viruses and eukaryotic microalgae (Mundt et al., 2001).Maximum antifungal activities in case of methanol extraction as observed in the present study are in accordance with earlier reports (Østensvik et al., 1998; Soltani et al., 2005). The effect of antimicrobial activity of cyanobacteria has been reported in other studies such as Patterson et al., (1994), Falch et al., (1995), and Smitka et al., (1992).

It seems Calothrix javanica is being reported for the first time as producer of antifungal substances. The results of this work indicate that this species displays a potential that warrants further investigations. No antifungal activity was detected in the hexane and aqueous extracts. This is probably because of polar nature of the active components. It shows that the chance of finding antifungal activity is higher in methanol extracts. The variation in antifungal activities could be due to different permeability of bioactive substances into the test organisms. The production of bioactive compounds and expression of antimicrobial activity depends on physiological factors such as stage of growth and culture conditions (Schlegel et.al.1999).

\section{REFERENCES:}

Black JG (1996) Microbiology: Principles and Application, Prentice Hall NJ pp.260.

Bolch C, Blackburn S (1996) isolation and purification of Australian isolates of the toxic cyanobacterium Microcystis aeruginosa. Kutz. J. Appl. Phycol. 8: 513

Browitzka MA (1995) Microalgae as sources of pharmaceuticals and other biologically active compounds. Appl. Phycol. 7: 315

De Pavia SR, Fig ueiredo MR, Aragao TV, Kaplan MAC (2003). Antimicrobial activity in vitro plumbagin isolated from Plumbago species. Mem. Inst. Oswaldo. Cruz, Rio deJaneiro, 98: 956-961

Desikachary TV (1959) A monograph on Cyanophyta, ICAR Publication, New Delhi.1-686

Fish SA, Codd GA (1994) Analysis of culture conditions controlling the yield of bioactive material produced by the thermo tolerent cyanobacterium (blue green alga) Phormidium. Eur. J. Phycol. 29: 261-266

Falch PS, Konig GM, Wright AD (1995) Biological activities of cyanobacteria: Evaluation of bacteria and pure compounds. Planta Med. 61:321-328

Hirsch CF, Liesch JM, Salvatore MJ, Schwartz RE, Sesin DF, Hirsch CF, Liesch JM, Salvatore MJ, Schwartz RE, Sesin DF (1990) Antifungal fermentation product and method. U.S. Patent 4,946,835

Ishibashi M, Moore RE, Patterson GML (1986) Scytophycins, cytotoxic and antimycotic agents from the cyanophyte Scytonema pseudohofmanni. J. Org. Chem. 51: 5300-5306

MacNeil IA, Tiong CL, Minor C, August PR, Grossman TH, Loiacono KA, Lynch BA, Phillips T, Narula S, Sundaramoorthi R, Tyler A, Aldredge T, Long H, Gilman M, HoltD, Osburne MS. (2001) Expression and isolation of antimicrobial small molecules from soil DNA libraries. J. Mol. Microbiol Biotechnol. 3: 301-308 
I J R B A T, Issue (VIII), Vol. II, May 2020: 92-95

11. Mundt S, Kreitlow S, Nowotny A, Effmert U (2001) Biological and pharmacological investigation of selected cyanobacteria. Int. J. Hyg. Environ. Health. 203: 327334

Olaizola M (2003) Commercial development of microalgal biotechnology: from the test tube to the marketplace. Biomol Eng 20: 459-466

Patterson GML, Carmeli S (1992) Biological effects of tolytoxins (6-Hydroxy-7-omethyl-Scytophyscin $\quad$ B) a potent bioactive metabolite from cynobactaria. Arch. Microbiol.157: 406-410

Patterson GML, Parker DL, Bolis CM (1994) Fungal cell wall polyaccaride elicit an antifungal 2 metabolite (phytoalexin) in the cyanobacterium Scytonema ocellatona. J. Phycol. 33: 54-60

Prescott GW (1962) Algae of the Western Great Lake Areas. WMC Brown Company Publisher, Dubuque Iowa

Rippka R, Deruelles J, Waterbury JB, Herd man M, Stainer RY (1979) Generic assignments. Strain histories and properties of pure cultures of cyanobacteria. J. Gen. Microbiol. 111: $1-61$

Schlegel I, Doan NT, De Chazol N, Smith GD (1999) Antibiotic activity of new cyanobacterial isolates fromAustralia and Asia against green algae and cyanobacteria. J. Appl. Phycol. 10: 471479

Selitrennikoff Claudep (2001) Antifungal Proteins J. Applied and Environmental Microbiology 67: 2883-2894

Smitka TA, Bonjouklian R, Doolin L, Jones ND,Deeter JB, Yoshida WY, Prinsep MR, Moore RE,Patterson GML(1992) Ambiguine isonitriles, fungicidal hapalindole-type alkaloids from three genera of blue-green algae belonging to Stigonemataceae. J. Org. Chem. 57: 857-861

Soltani N, Khavari-Nejad RA, Yazdi MT, Shokravi S, Ferna'ndez- Valiente E. (2005) Screening of soil cyanobacteria for antifungal and antibacterial activity. Pharm. Biol. 43: 455-459

Stensvik, Skulberg, OM, Underdal B, Hormazabal V (1998) Antibacterial properties of extracts from selected plaktonic freshwater cyanobacteria-a comparative study of bacterial bioassays. The Society for Applied Microbiology. 84: 1117-1124.

Trimurtulu, G, Ohtani I, Patterson GML, Moore RE, Corbett TH, Valeriote FA, Demchik L (1994) Total structures of cryptophycins, potent antitumor depsi peptidesfrom the blue-green alga Nostoc sp. strain GSV 224. J. Am. Chem. Soc. 116: 4729-4737

Table no.-1: Antifungal activity of methanol and chloroform extract of Calothrix javanica at $400 \mu \mathrm{g} / \mathrm{ml}$ concentration against some species of fungi.

\begin{tabular}{|c|c|c|c|c|c|c|c|}
\hline \multirow[b]{2}{*}{ Extract } & \multicolumn{7}{|c|}{ Diameter of effective zone of inhibition ( $\mathrm{mm}$ ) } \\
\hline & $\begin{array}{l}\text { Aspergillu } \\
\text { s niger }\end{array}$ & $\begin{array}{l}\text { Trichophyton } \\
\text { capitanum }\end{array}$ & $\begin{array}{l}\text { Fusarium } \\
\text { monelliforme }\end{array}$ & $\begin{array}{l}\text { Candida } \\
\text { aibicans }\end{array}$ & $\begin{array}{l}\text { Helminthos } \\
\text { porium sp. }\end{array}$ & $\begin{array}{l}\text { Alternaria } \\
\text { sp. }\end{array}$ & $\begin{array}{l}\text { Aspergillus } \\
\text { flavus }\end{array}$ \\
\hline Methanol & $6 \pm 1.3$ & $11 \pm 1.8$ & $16 \pm 1.5$ & $10 \pm 1.7$ & $8 \pm 1.8$ & $11 \pm 1.3$ & $17 \pm 1.5$ \\
\hline Chloroform & $11 \pm 1.3$ & --- & --- & --- & --- & ---- & $09 \pm 1.4$ \\
\hline Hexane & --- & $\begin{array}{ll}-- \\
\end{array}$ & --- & --- & --- & --- & --- \\
\hline $\begin{array}{l}\text { Aqueous } \\
\text { extract }\end{array}$ & --- & --- & --- & --- & --- & --- & --- \\
\hline $\begin{array}{l}\text { Itraconazole( } \\
10 \mu \mathrm{gml}^{-1)}\end{array}$ & $22 \pm 2.4$ & $28 \pm 1.3$ & $25 \pm 1.7$ & $22 \pm 1.6$ & $28 \pm 1.2$ & $30 \pm 1.2$ & $28 \pm 1.2$ \\
\hline
\end{tabular}

